\title{
Glucose Utilization in a Patient with Hepatoma and Hypoglycemia Assessment by a Positron Emission Tomography
}

\author{
Richard C. Eastman," Richard E. Carson," David G. Orloff," Craig S. Cochran," James F. Perdue," Matthew M. Rechler,"*

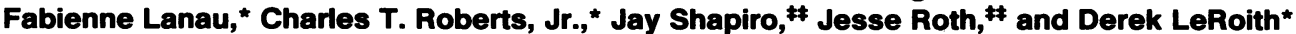 \\ *Diabetes Branch, National Institute of Diabetes, and Digestive and Kidney Diseases (NIDDK), National Institutes of Health (NIH), \\ Bethesda, Maryland 20892; 'Department of Positron Emission Tomography, Clinical Center, NIH, Bethesda, Maryland 20892; ${ }^{8}$ Cell \\ Biology and Metabolism Branch, National Institute of Child Health and Human Development, NIH, Bethesda, Maryland 20892; \\ "Department of Nursing, Clinical Center, NIH, Bethesda, Maryland 20892; 'Laboratory of Molecular Biology, Jerome H. Holland \\ Laboratory for the Biomedical Sciences, American Red Cross, Rockville, Maryland 20855; **Molecular, Cellular, and Nutritional \\ Endocrinology Branch, Growth and Development Section, NIDDK, NIH, Bethesda, Maryland 20892; and ${ }^{\ddagger} J o h n s$ Hopkins University \\ School of Medicine, Division of Geriatric Medicine and Gerontology, Bayview Research Campus, Johns Hopkins Allergy and Asthma \\ Center, Baltimore, Maryland 21224
}

\begin{abstract}
Tumor glucose use in patients with non-islet-cell tumors has been difficult to measure, particularly in hepatoma, because of hepatic involvement by neoplasm. We studied a patient with nonhepatic recurrence of hepatoma after successful liver transplantation. Tumor tissue contained messenger RNA for insulinlike growth factor-II (IGF-II), and circulating high molecular weight components and E-peptide of IGF-II were increased. Glucose use measured by isotope dilution with $\left[3-{ }^{3} \mathrm{H}\right]$ glucose was $7.94 \mathrm{mg} / \mathrm{kg}$ fat-free mass per min, and splanchnic glucose production was $0.93 \mathrm{mg} / \mathrm{kg}$ fat-free mass per min. Glucose uptake and glucose model parameters were independently measured in tissues by positron emission tomography with ${ }^{18} \mathrm{~F}$ fluoro-2-deoxy-D-glucose. Glucose uptake by heart muscle, liver, skeletal muscle, and neoplasm accounted for $0.8,14,44$, and $15 \%$ of total glucose use, respectively. Model parameters in liver and neoplasm were not significantly different, and glucose transport and phosphorylation were twofold and fourfold greater than in muscle. This suggests that circulating IGF-IIlike proteins are partial insulin agonists, and that hypoglycemia in hepatoma with IGF-II production is predominantly due to glucose uptake by skeletal muscle and suppression of glucose production. (J. Clin. Invest. 1992. 89:1958-1963.) Key words: hypoglycemia $\bullet$ hepatoma $\bullet$ insulin-like growth factor-II - positron emission tomography • non-islet-cell tumor
\end{abstract}

\section{Introduction}

Primary hepatocellular carcinoma is frequently complicated by hypoglycemia, which may occur as a terminal event due to hepatic failure (type A presentation), or in some cases, early in the course of the disease (type B presentation) $(1,2)$. The latter patients have many features in common with other patients with non-islet-cell tumor hypoglycemia due to mesenchymal

Address correspondence and reprint requests to Dr. Richard C. Eastman, Acting Director, Division of Diabetes, Endocrinology and Metabolism, National Institute of Diabetes, and Digestive and Kidney Diseases, National Institutes of Health, Building 31, Room 9A-16, Bethesda, MD 20892.

Received for publication 11 October 1991 and in revised form 3 February 1992.

The Journal of Clinical Investigation, Inc.

Volume 89, June 1992, 1958-1963 or epithelial tumors, namely, production of insulin-like growth factor II (IGF-II) ${ }^{1}$ protein (3-12). Studies of the mechanism of hypoglycemia have implicated suppression of splanchnic glucose production and stimulation of peripheral glucose use, as well as functional growth hormone deficiency (8-10, 13-20). Use of glucose by the neoplasm is an additional factor that has been considered and studied in a few cases, but has been difficult to measure (21-24). Study of hepatic glucose metabolism in patients with hepatoma is complicated by the possibility of local effects of the tumor on hepatic function, and has not been performed using modern techniques.

We had the rare opportunity to study a patient with primary hepatoma who had undergone successful liver transplantation, but who developed hypoglycemia coincident with extrahepatic recurrence of the neoplasm. This allowed assessment of liver glucose metabolism in a patient whose liver was free of tumor. We used positron emission tomography (PET) with fluorodeoxyglucose, a noninvasive technique that has been used to measure glucose metabolism in normal and neoplastic tissues $(25,26)$, in conjunction with measurement of glucose turnover by isotope dilution to assess the effects of the tumor on whole body metabolism and the contribution of tumor glucose use to hypoglycemia.

A 33-yr-old black male presented with a bleeding duodenal ulcer in July 1988. At surgery, the liver was found to be involved with tumor, and biopsy showed hepatocellular carcinoma. Staging workup showed no evidence of metastases, and in May 1989 he underwent an orthotopic liver transplant. Regional lymph nodes were negative for metastases. He was treated with cyclosporin A and prednisone posttransplant, and did well until December 1989 when he presented with symptoms of acute hypoglycemia and a glucose of $1.12 \mathrm{mM}$. Chest $\mathrm{x}$ ray showed multiple metastases, and abdominal computerized tomography (CT) scan showed a large retroperitoneal mass on the right. Somatostatin analogue was without benefit. The patient was maintained on a dextrose infusion $(150 \mathrm{ml} / \mathrm{h}$ of $10 \%$ dextrose), and was treated with six cycles of cytoxan, adriamycin, and vincristine. He responded partially, but continued to require dextrose infusions. 3 mo after completing this treat-

1. Abbreviations used in this paper: ANOVA, analysis of variance; CT, computerized tomography; FDG, ${ }^{18} \mathrm{~F}$-2-deoxyglucose; ffm, fat-free mass; FMR, fractional metabolic rate; GH, growth hormone; IGF-II, insulin-like growth factor-II; PET, positron emission tomography; Rd, total glucose use. 
ment, he again presented with hypoglycemia and received two cycles of cysplatinum and etoposide. Hypoglycemia persisted and he was referred to the National Institutes of Health (NIH) for evaluation. On admission, the patient was taking prednisone $30 \mathrm{mg} / \mathrm{d}$, cyclosporin A $500 \mathrm{mg} / \mathrm{d}$, and dapsone $100 \mathrm{mg} / \mathrm{d}$. On physical examination, the patient was $188 \mathrm{~cm}$ tall and weighed $68.2 \mathrm{~kg}$. An irregular mass was palpable in the right abdomen extending from the costal margin to the iliac crest. Abdominal CT showed a large retroperitoneal mass on the right involving the capsule of the liver and the abdominal wall. Routine liver chemistries were essentially normal during the period of study.

The patient subsequently died of acute rejection of the liver transplant. Postmortem examination confirmed that the liver was essentially free of neoplasm, except for minimal invasion of the capsule of the right lobe.

\section{Methods}

Tumor glucose use was determined by dynamic PET with ${ }^{18} \mathrm{~F}$-2-deoxyglucose (FDG), using a body scanner (Posicam 6.5; Positron Corp., Houston, TX). The study was performed after an overnight fast with $20 \%$ dextrose in water running continuously to maintain the patient's blood glucose. The dextrose infusion was continued during the PET scan. The PET study was initiated by injecting $5 \mathrm{mCi}$ of FDG as an intravenous bolus over $2 \mathrm{~min}$. Arterial plasma radioactivity was determined by rapid sampling of arterial blood through an indwelling radial artery catheter at intervals of $15 \mathrm{~s}$ initially, decreasing to $10 \mathrm{~min}$ by the end of the study (120 min). Coincidence data were collected continuously in list mode and were later reformatted and reconstructed to produce images with in-plane resolution of $9 \mathrm{~mm}$. The PET scan was registered to a CT scan for the purpose of identifying anatomical regions of interest. PET scans were analyzed using the MIRAGE image analysis system (Department of Nuclear Medicine, NIH, Bethesda, MD). Time activity curves for elliptical regions of interest in heart, liver, forearm, and paraspinal muscle were analyzed. Fractional FDG uptake $\left(K_{1} k_{3} /\left(k_{2}+k_{3}\right)\right.$, inward glucose transport $\left(K_{1}\right)$, outward transport $\left(k_{2}\right)$, phosphorylation $\left(k_{3}\right)$, and dephosphorylation of glucose-6phosphate $\left(k_{4}\right)$ were estimated by nonlinear least squares optimization using a two-compartment model that included the blood pool. Plasma radioactivity was corrected for metabolites of FDG. Rates of glucose use were determined from the average plasma glucose during the uptake period $(8.7 \mathrm{mM})$, fractional metabolic rate for FDG, and lumped constant, as previously described $(25,27,28)$.

The lumped constant is an empirically derived constant that is used to determine the rate of glucose uptake from the fractional rate of FDG uptake derived from the PET scans. We used literature values for the lumped constant of 0.67 (29) for myocardium and 1.0 for muscle (30), and assumed that the constant was 1 for liver and for neoplasm. Glucose use was also compared in regions of interest by Patlak analysis $(31,32)$.

To determine organ and tumor glucose use, the volume of the neoplasm and liver were measured from chest and abdominal CT scans, using a conversion factor of $0.198 \mathrm{ml} / \mathrm{pixel}$. The neoplasm was 1,487 $\mathrm{ml}$ and the liver $2,071 \mathrm{ml}$. For estimation of tissue weight, the density was assumed to be $1 \mathrm{~g} / \mathrm{ml}$, and the heart was assumed to weigh $325 \mathrm{~g}$.

Glucose turnover was measured by primed $(0.3 \mu \mathrm{Ci})$ continuous infusion $(0.3 \mu \mathrm{Ci} / \mathrm{min})$ of $\left[3-{ }^{3} \mathrm{H}\right]$ glucose (gift from Dr. C. Bogardus NIDDK, Phoenix, AZ), and started at the same time as the injection of FDG for the PET scan. Glucose turnover $\left(\boldsymbol{R}_{\mathrm{a}}\right)$ was calculated using the non-steady-state equation of Steele (33), as modified by DeBodo (34), using a pool volume of $210 \mathrm{ml}(35)$ and a pool fraction of $0.653(36)$. Hepatic glucose production was calculated by subtracting the steadystate glucose infusion rate from $R_{\mathrm{a}}$. Body fat was estimated by transdermal infrared spectroscopy (Futrex 5000; Futrex Inc., Gaithersburg, MD), an empirical technique that correlates highly with results ob- tained using underwater weighing in adults and children over a wide range of body weights and body fat. Although this technique has not been validated in patients with malignancy, the test yielded a result of $10.3 \%$, which was consistent with the patient's physical examination which showed reduced subcutaneous tissue with good muscle mass. The patient did not appear cachectic at the time of study. Glucose turnover, hepatic glucose production, and tumor glucose use are expressed as $\mathrm{mg} / \mathrm{kg} \cdot \mathrm{ffm}$ (fat-free mass) $(61.6 \mathrm{~kg}) / \mathrm{min}$. Muscle mass was estimated to be $34.9 \%$ of ffm body mass $(21.5 \mathrm{~kg})(37)$.

RNA was extracted from tumor and normal tissue using guanidinium thiocyanate and $\mathrm{LiCl}$ precipitation, as previously described (38). Solution hybridization/RNAase protection assays were performed with 20- $\mu \mathrm{g}$ aliquots of total RNA from the tumor, as well as from liver, spleen, and kidney (39). Samples were hybridized with an antisense RNA probe complimentary to the human IGF-II mRNA sequence in the 5 -untranslated region and the region encoding part of the mature peptide (40).

Blood levels of IGF-I, IGF-II, glucagon, growth hormone, and insulin were measured by RIA, and catecholamines by HPLC (Nichols Institute, San Juan Capistrano, CA).

IGF-II components were measured using a rat placental membrane radioreceptor assay after SePpak C-18 purification (41). High molecular mass (15,000 D) IGF-II was estimated by radioimmunoassay, using an antibody against the E-peptide of the prohormone (41a). Western ligand blot showed IGF BP-3 and IGF BP-2 as major IGFBPs, as reported by Zapf (42).

Data are expressed as mean $\pm \mathrm{SD}$, unless otherwise indicated. Analysis of variance (ANOVA) was used for testing the null hypothesis that the rate parameters of glucose metabolism were the same in the tissues studied. If the ANOVA showed a $P<0.05$, post hoc Newman-Keul's tests were used to determine significant differences between individual tissues (43). A $P<0.05$ was considered statistically significant.

This patient was studied under protocol 87-DK-188, which was approved by the clinical research subpanel of the National Cancer Institute. Informed consent was obtained.

\section{Results}

To assess the etiology of the patient's hypoglycemia, the dextrose infusion was interrupted and the patient's blood glucose measured every $10 \mathrm{~min}$ for $2 \mathrm{~h}$. The blood glucose fell to 1.12 $\mathrm{mM}$, at which time the patient was alert and oriented. At the time of hypoglycemia growth hormone (GH) and insulin were undetectable, glucagon was 12 pM (4-20 normal), epinephrine $2,574 \mathrm{pM}$ ( $<495$ normal), norepinephrine 4.4 pM $(<3.6$ normal). The patient was not ketotic. IGF-I was $0.1 \mathrm{U} / \mathrm{ml}$ (0.3-1.9 normal) and IGF-II $667 \mathrm{ng} / \mathrm{ml}$ (358-854 normal). After C18 chromatography and radioreceptor assay, the concentration of $M_{\mathrm{r}} 7,500$ IGF-II was $970 \pm 263 \mathrm{ng} / \mathrm{ml}$ (normal $664 \pm 263 \mathrm{ng} / \mathrm{ml}$ ), $M_{\mathrm{r}} 2,400$ material (E-peptide) $76 \pm 8 \mathrm{ng} / \mathrm{ml}$ (normal $20 \pm 5 \mathrm{ng} /$ $\mathrm{ml}$ ), and $M_{\mathrm{r}} 15,000$ material $317 \pm 31 \mathrm{ng} / \mathrm{ml}$ (normal $84 \pm 21$ $\mathrm{ng} / \mathrm{ml}$ ). Relative to total circulating IGF-II the $M_{\mathrm{r}} 15,000$ material represented $32 \%$ of the total activity, compared with $12.7 \%$ in normal serum, and E-peptide represented $8 \%$, compared with $3 \%$ in normal serum. A solution hybridization/RNAase protection assay demonstrated a distinct hybridizing band with tumor RNA corresponding to typical IGF-II mRNA that was not seen in tissue from kidney, liver, or spleen.

During the PET scan the rates of glucose use and glucose production were 7.74 and $0.93 \mathrm{mg} / \mathrm{kg} \cdot \mathrm{ffm}$ per min, respectively. The accumulation of ${ }^{18} \mathrm{~F}$ radioactivity by liver and neoplasm were similar, reaching 90,160 , and $305 \mathrm{nCi} / \mathrm{ml}$ of tissue, respectively (Fig. 1). Patlak plot analysis of these data showed that the distribution volume of FDG in heart muscle and liver 


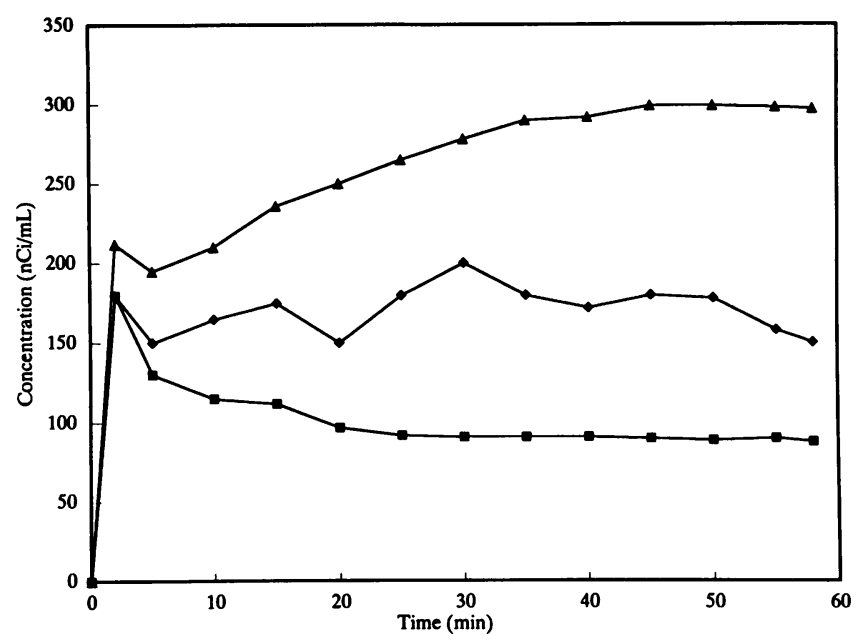

Figure 1. Tissue uptake of ${ }^{18} \mathrm{~F}$-radioactivity plotted as a function of time for representative regions of myocardium (- -), liver ( - - ), and neoplasm (- -$)$. Data are expressed as $\mathrm{nCi} / \mathrm{ml}$ of tissue.

reached steady state with respect to accumulation of radioactivity, while the tumor regions continued to accumulate radioactivity with time, and are consistent with metabolic rates for glucose in the order of neoplasm $>$ liver $>$ myocardium.

Table I depicts the results of analysis glucose metabolism of heart, liver, skeletal muscle, and neoplasm from the PET scans. Shown are the rate constants (mean \pm SD) derived from the time-activity curves for each region, and the calculated metabolic rates for each tissue expressed per $100 \mathrm{~g}$ of tissue (MR tissue) and as milligrams fat-free body mass per minute (MR body). These rates are also expressed as a percent of total glucose use (\% Rd), determined by isotope dilution. We determined that tumor glucose use accounted for $15 \%$ of total glucose use, or $105 \mathrm{~g} / \mathrm{d}(71 \mathrm{mg} / \mathrm{g}$ tumor per d). This is in the range of prior reports of $11-120 \mathrm{mg} / \mathrm{g}$ neoplasm per day based on direct measurement of glucose use in vitro in tumor tissue from patients with non-islet-cell tumors and hypoglycemia $(13,14$, $16,21-24)$. The rate of glucose use is also consistent with studies of musculoskeletal tumors of the extremities in patients without hypoglycemia, where the mean rate of glucose use estimated by PET ranged from 37 to $131 \mathrm{mg} / \mathrm{g}$ neoplasm per d (26).

Analysis of the rate parameters for glucose metabolism showed that glucose transport by the neoplasm $\left(K_{1}\right)$ was significantly greater than in heart and skeletal muscle, but was not significantly different from liver. No significant difference in outward glucose transport $\left(k_{2}\right)$ was observed. The group $P$ (ANOVA) for $k_{3}$ was significant $(P=0.0241)$, but post hoc analysis did not show significant differences between the tissues, probably due to the large errors in parameter estimation. Loss of radioactivity from the tissues $\left(k_{4}\right)$ was negligible for myocardium and skeletal muscle, and was similar for liver and tumor. Liver and neoplasm metabolized two to four times more glucose per volume of tissue than heart and skeletal muscle (Table I).

\section{Discussion}

Hypoglycemia developing early in the course of hepatocellular carcinoma is a distinct clinical syndrome (type B) that is less common than the development of hypoglycemia during the terminal stages of the disease due to liver failure (type A) (1). The type $B$ presentation is common in patients with hepatocellular carcinoma in Hong Kong, occurring in $13 \%$ of patients, but is rare in western countries (2). Our patient has the features of the type B presentation. Hypoglycemia occurred early in the course of the disease when there was no evidence of liver involvement or failure, and required infusions of dextrose to maintain hypoglycemia. Our patient also showed biochemical features that have been described in this syndrome, namely suppression of insulin and IGF-I, expression of mRNA for IGF-II by the neoplasm, and circulating higher molecular weight components of IGF-II precursor $(5,6)$. Similar findings have been reported in patients with mesenchymal tumors and hypoglycemia $(3,4,8-11,43 a-47)$.

Hypoglycemia in association with non-islet-cell tumors has been attributed to production of IGF-II-like proteins by the tumor, counterregulatory hormone deficiency, and glucose use by tumor (48). Studies of glucose metabolism in affected patients with mesenchymal tumors demonstrated variable suppression of splanchnic glucose production and stimulation of peripheral glucose use (14-20), but have not used modern techniques to study patients with hepatoma $(1,2,13)$. Our patient offered a rare opportunity to study liver and tumor glucose metabolism without the interpretation of the results being complicated by the presence of tumor in the liver.

We observed partial suppression of splanchnic glucose production to about $42 \%$ of the rate seen in normal subjects in the postabsorptive state $(2.2 \mathrm{mg} / \mathrm{kg}$ per min), similar to the early report by Landau (13). The absence of maximal rates of glucose production in the face of absent insulin by RIA is presumably due to circulating IGF-related peptides, although GH deficiency and subnormal glucagon response to hypoglycemia may have been contributing factors (49). GH treatment has transiently improved hypoglycemia, and glucagon given by infusion pump for $16 \mathrm{wk}$ improved hypoglycemia in a patient with a neurofibrosarcoma (50). Alpha and beta cells of the islets of Langerhans have receptors for IGF, and IGF infusion suppressed insulin and glucagon release from the isolated perfused rat pancreas. Thus, direct action of IGF on alpha cells may explain the inappropriate levels of glucagon observed during hypoglycemia in our patient (51).

In the postabsorptive state in normal man, $\sim 20 \%$ of glucose use is by liver, $60 \%$ by brain, and $20 \%$ by muscle and other tissues (52). During a hyperinsulinemic, euglycemic glucose clamp the corresponding percentages of total glucose use are 5, 10 , and $85 \%(52)$. The glucose use rate in our patient $(7.74$ $\mathrm{mg} / \mathrm{kg} \cdot \mathrm{ffm}$ per $\mathrm{min}$ ) is similar to maximally insulinized, insulin-sensitive subjects, and is remarkable because insulin levels were undetected by RIA and the patient was taking prednisone, an agent that produces insulin resistance at the postreceptor level (53).

Our findings are quite different than in patients with advanced malignancy without hypoglycemia. Cerosimo et al. studied glucose turnover using similar techniques to ours in patients with cancer cachexia (54). They observed increased basal glucose production $(2.9 \mathrm{mg} / \mathrm{kg}$ per $\mathrm{min})$ in the postabsorptive state, and a slight rightward shift in the hepatic doseresponse curve for suppression of glucose production. The dose-response curve for peripheral glucose uptake demonstrated a decrease in $V_{\max }$, compared with control subjects. Our studies are strikingly different because in the postabsorptive 
Table I. Model Parameters and Glucose Use Determined from the PET Scans

\begin{tabular}{|c|c|c|c|c|c|c|c|c|c|c|c|}
\hline Parameter & $K 1$ & $k 2$ & $k 3$ & $k 4$ & $K 1 / k 2$ & $K 1 \operatorname{per}(k 2+k 3)$ & FMR & $\begin{array}{c}\text { MR } \\
\text { Tissue }\end{array}$ & $\begin{array}{c}\text { MR } \\
\text { Body }\end{array}$ & $\begin{array}{c}\text { Percentage of } \\
\text { Rd }\end{array}$ & Glucose use \\
\hline \multicolumn{12}{|l|}{ Heart } \\
\hline Mean & 0.0413 & 0.1387 & 0.0222 & -0.0147 & 0.3088 & 0.2757 & 0.0050 & 1.16 & 0.06 & $0.8 \%$ & 5 \\
\hline SD & 0.0257 & 0.0499 & 0.0226 & 0.0261 & 0.0681 & 0.0818 & 0.0038 & & & & \\
\hline \multicolumn{12}{|l|}{ Liver } \\
\hline Mean & 0.0846 & 0.2441 & 0.0926 & 0.0242 & 0.3966 & 0.2993 & 0.0213 & 3.30 & 1.12 & $14 \%$ & 98 \\
\hline SD & 0.1670 & 0.1287 & 0.0789 & 0.0162 & 0.1262 & 0.1112 & 0.0096 & & & & \\
\hline \multicolumn{12}{|l|}{ Muscle } \\
\hline Mean & 0.0387 & 0.299 & 0.0861 & 0.0065 & 0.1658 & 0.1258 & 0.0063 & 0.97 & 3.39 & $44 \%$ & 301 \\
\hline SD & 0.0281 & 0.2609 & 0.103 & 0.0428 & 0.0762 & 0.065 & 0.003 & & & & \\
\hline \multicolumn{12}{|l|}{ Neoplasm } \\
\hline Mean & 0.0847 & 0.1616 & 0.0970 & 0.0183 & 0.5538 & 0.3436 & 0.0317 & 4.91 & 1.19 & $15 \%$ & 105 \\
\hline $\mathrm{SD}$ & 0.0134 & 0.0686 & 0.0317 & 0.0068 & 0.1548 & 0.0949 & 0.0069 & & & & \\
\hline Subtotal total & & & & & & & & & 5.71 & $74 \%$ & 510 \\
\hline Unaccounted for & & & & & & & & & 2.03 & $26 \%$ & 177 \\
\hline Total Rd & & & & & & & & & 7.74 & $100 \%$ & 687 \\
\hline ANOVA $P=$ & 0.0001 & NS & 0.0241 & 0.0088 & 0.0001 & 0.0001 & 0.0001 & & & & \\
\hline \multicolumn{12}{|l|}{ Newman-Keul's } \\
\hline \multicolumn{12}{|c|}{$P<$ value shown } \\
\hline$H$ vs $L$ & 0.01 & NS & NS & 0.05 & NS & NS & 0.01 & & & & \\
\hline$H$ vs $M$ & NS & NS & NS & NS & NS & 0.05 & NS & & & & \\
\hline $\mathrm{H}$ vs $\mathrm{T}$ & 0.01 & NS & NS & 0.05 & 0.01 & NS & 0.01 & & & & \\
\hline L vs $M$ & 0.01 & NS & NS & NS & 0.05 & 0.05 & 0.01 & & & & \\
\hline $\mathrm{L}$ vs $\mathrm{T}$ & NS & NS & NS & NS & 0.05 & NS & 0.01 & & & & \\
\hline T vs $M$ & 0.01 & NS & NS & NS & 0.01 & 0.01 & 0.01 & & & & \\
\hline
\end{tabular}

Model parameters and fractional metabolic rate of FDG (FMR) were determined by least squares estimation of regions of interest in heart, liver, skeletal muscle, and tumor. The metabolic rate of the tissues (MR Tissue) were calculated by multiplying the fractional metabolic rate (FMR) for the tissue by the mean glucose during the PET scan and dividing by the lumped constant, and are expressed as milligrams glucose/100 $\mathrm{g}$ tissue per min. The contribution of tissue glucose use to whole body glucose use (MR Body), was determined by multiplying MR Tissue $\times$ tissue weight, and are expressed as $\mathrm{mg}$ glucose/ $\mathrm{kg}$ fat-free body mass per min. Values for MR body are also expressed as the percent of Rd, determined by isotope dilution with tritiated glucose. The last column of the table gives the amount of glucose used by each tissue in grams per day. ANOVA was performed on each of the rate parameters, and the group " $P$ " value determined (ANOVA $P$ ). Post hoc comparisons of heart (H), liver (L), muscle (M), and tumor (T) by Newman-Keul's tests are shown at the bottom of the table, with the comparison tissues (i.e., $\mathrm{H}$ vs $\mathrm{L}$ ) on the left, and the significance for each model parameter under the corresponding columns. For all tests $P$ values are less than the number shown, and NS, not significant.

state in our patient basal glucose production was $30 \%$ of the rate observed by Cerosimo et al., despite suppression of insulin secretion to undetectable levels. Furthermore, in our patient peripheral glucose uptake was similar to the rate observed in the patients with malignancy at insulin concentrations of $\sim 200 \mu \mathrm{U} / \mathrm{ml}$, again despite unmeasurable insulin. Their patients may not be comparable with our patient, in that their patients had a mean weight of $63 \mathrm{~kg}$ and were considered cachectic, whereas the degree of weight loss was less in our patient, who did not appear cachectic.

Using the PET scans to make an independent measure of tissue glucose uptake, we found that $14 \%$ of glucose was used by liver, $44 \%$ by muscle, and $15 \%$ by the neoplasm, leaving $26 \%$ of total glucose use unaccounted for (Table I). If we assume normal brain glucose use of $0.6 * 2.2 \mathrm{mg} / \mathrm{kg}$ per $\min (1.32 \mathrm{mg} /$ $\mathrm{kg}$ per min), brain glucose use would account for about $17 \%$ of glucose use, leaving about $10 \%$ for metabolism by other tissues. Thus the physiology in this patient was intermediate between the postabsorptive state and maximal insulinization, with less suppression of hepatic glucose production and less stimulation of muscle glucose use than observed in the maximally insulin- ized normal subject, and suggests that circulating IGF-II-like peptides are partial insulin agonists. The effects on muscle are probably mediated through the type I IGF receptor (55), and through the insulin receptor in adipose tissue and liver (56).

Previous estimates of tumor glucose use have been based on measurement of A-V differences across the tumor or on extrapolation from in vitro studies of tumor tissue, and have ranged from 8 to $139 \mathrm{mg} / \mathrm{kg}$ tumor per $\min (13,14,16,21-24)$. The rate of tumor glucose use measured from the PET scans in our patient, $49 \mathrm{mg} / \mathrm{kg}$ neoplasm per min, is consistent with these reports. The high rates of glucose use are thought to be due to increased anaerobic glycolysis resulting from a deficient Pasteur effect in the tumor (57).

The rate of inward glucose transport, represented by $K_{1}$ in the glucose model, was the same in liver and neoplasm, was significantly greater than in myocardium and skeletal muscle (Table I), and was similar to the rate of transport estimated by PET in gray matter $(0.1020)(58)$. This confirms that glucose transport in hepatoma, like liver and brain, is hormone independent (21). Myocardial glucose use ( $1.16 \mathrm{mg} / 100 \mathrm{~g}$ per min) was intermediate between rates at rest $(0.22 \mathrm{mg} / 100 \mathrm{~g}$ per min) 
and during hyperinsulinemia $(21 \mathrm{mg} / 100 \mathrm{~g}$ per min), consistent with a weak effect of IGF-like peptides, probably mediated through IGF receptors $(59,60)$. The relative ratio of heart/skeletal muscle uptake was 1.19 , in contrast to studies with hyperinsulinemia where myocardial uptake is $\approx 15$-fold greater (60). We also observed negligible $k_{4}$ in myocardium and skeletal muscle, with the value for skeletal muscle similar to that reported for brain $(0.0065)(58)$. Our findings are consistent with the absence of significant glucose-6-phosphatase activity in myocardium and skeletal muscle, and with continued hepatic glucose production in our patient.

The amount of glucose use by the neoplasm in our patient was relatively small in comparison with total glucose use, and the rate of use was similar to normal tissues (i.e., liver) and to rates of glucose use in musculoskeletal tumors of the extremities not associated with hypoglycemia (26). Thus, glucose use by the neoplasm, while contributing to the total glucose requirement, would be insufficient to produce hypoglycemia unless homeostatic mechanisms were impaired, as they were in this patient. Stimulation of glucose uptake by muscle played the greatest role in producing hypoglycemia, and glucose production by splanchnic tissues was partially impaired, although not to the extent seen in insulinized patients with high rates of glucose uptake.

Mesenchymal and epithelial tumors associated with hypoglycemia are usually large at the time of diagnosis, and are more likely to be located in anatomical sites where a large tumor burden can develop with relatively minor symptoms of mass effect (61). For example, fibrosarcoma, the mesenchymal neoplasm most commonly reported with hypoglycemia, occurs most commonly in the extremities, yet is associated with hypoglycemia when it occurs in the retroperitoneal space, abdomen, pelvis, or thorax. This is probably because IGF-II-like proteins are partial insulin agonists, and protein production may be inefficient.

\section{Acknowledgments}

We wish to thank Dr. Thomas J. Giordano, Dr. Karen Schmidt, Dr. William D. Travis, and Dr. David Katz in the Department of Anatomical Pathology for providing tissue samples, and G. Paul Baldwin, Stacy Stein, Gerard I. Jacobs, Mel Packer, and Sheilah Green of the Department of Positron Emission Tomography, Clinical Center, National Institutes of Health, for assistance with these studies.

\section{References}

1. McFadzean, A. J. S., and R. T. T. Yeung. 1969. Further observations on hypoglycemia in hepatocellular carcinoma. Am. J. Med. 47:220-235.

2. Marchesini, G., and G. Bianchi. 1989. Carbohydrate metabolism in hepatocellular carcinoma: where does the glucose go. Hepatology. 10:253-255. (Editorial)

3. Megyesi, K., C. R. Kahn, J. Roth, and P. Gorden. 1974. Hypoglycemia in association with extrapancreatic tumors: demonstration of elevated plasma NSILA-s by a new radioreceptor assay. J. Clin. Endocrinol. \& Metab. 38:931934.

4. Gorden, P., C. M. Hendricks, C. R. Kahn, K. Megyesi, and J. Roth. 1981 Hypoglycemia associated with non-islet-cell tumor and insulin-like growth factors. N. Engl. J. Med. 305:1452-1455.

5. Wu, J.-C., W. H. Daughaday, S.-D. Lee, T. S. Hsiao, C.-K Chou, H.-D. Lin, Y.-T. Tsai, and B. N. Chiang. 1988. Radioimmunoassay of serum IGF-I and IGF-II in patients with chronic liver diseases and hepatocellular carcinoma with or without hypoglycemia. J. Lab. Clin. Med. 112:589-594.

6. Shapiro, E. T., G. I. Bell, K. S. Polonsky, A. H. Rubenstein, M. C. Kew, and H. S. Tager. 1990. Tumor hypoglycemia: relationship to high molecular weight insulin-like growth factor-II. J. Clin. Invest. 85:1672-1679.
7. Hyodo, T., K. Megyesi, C. R. Kahn, J. P. McLean, and H. Friesen. 1977. Adrenocortical carcinoma and hypoglycemia: evidence for production of nonsuppressible insulin-like activity by the tumour. J. Clin. Endocrinol. \& Metab. 44:1175-1184.

8. Merimee, T. J. 1986. Insulin-like growth factors in patients with nonislet cell tumors and hypoglycemia. Metab. Clin. Exp. 35:360-363.

9. Daughaday, W. H., M. A. Emanuele, M. H. Brooks, A. L. Barbato, M. Kapadia, and P. Rotwein. 1988. Synthesis and secretion of insulin-like growth factor II by a leiomyosarcoma with associated hypoglycemia. $N$. Engl. J. Med. 319:1434-1440.

10. Ron, D., A. C. Powers, M. R. Pandian, J. E. Godine, and L. Axelrod. 1989. Increased insulin-like growth factor II production and consequent suppression of growth hormone secretion: a dual mechanism for tumor-induced hypoglycemia. J. Clin. Endocrinol: \& Metab. 68:701-706.

11. Lowe, W. L., C. T. Roberts, Jr., D. LeRoith, M. T. Rojeski, T. J. Merimee, S. T. Fui, H. Keen, D. Arnold, J. Mersey, S. Gluzman, et al. 1989. Insulin-like growth factor-II in nonislet cell tumors associated with hypoglycemia: increased levels of messenger ribonucleic acid. J. Clin. Endocrinol. \& Metab. 69:11531159.

12. Teale, J. D., and V. Marks. 1990. Inappropriately elevated plasma insulinlike growth factor II in relation to suppressed insulin-like growth factor I in the diagnosis of non-islet cell tumor hypoglycemia. Clin. Endocrinol. 33:87-98.

13. Landau, B. R., N. Wills, J. W. Craig, J. R. Leonards, and T. Moriwaki. 1962. The mechanism of hepatoma-induced hypoglycemia. Cancer (Phila.). 15:1188-1196.

14. Nissan, S., A. Bar-Maor, and E. Shafrir. 1968. Hypoglycemia associated with extrapancreatic tumors. N. Engl. J. Med. 278:177-183.

15. Kreisberg, R. A., J. M. Hershman, J. G. Spenney, B. R. Boshell, and L. F. Pennington. 1970. Biochemistry of extrapancreatic tumor hypoglycemia. Diabetes. 19:248-258.

16. Frerichs, H., W. H. Kasper, C. Creutzfeldt, and W. Creutzfeldt. 1970. Contribution to the pathogenesis of tumour hypoglycemia. Eur. J. Clin. Invest. $1: 2-11$.

17. Chandalia, H. B., and B. R. Boshell. 1972. Hypoglycemia associated with extrapancreatic tumors. Arch. Intern. Med. 129:447-456.

18. Silbert, C. K., A. A. Rossini, S. Ghazvinian, W. C. Widrich, L. J. Marks, and C. T. Sawin. 1976. Tumor hypoglycemia: deficient splanchnic glucose output and deficient glucagon secretion. Diabetes. 25:202-206.

19. Benn, J. J., R. G. R. Firth, and P. H. Sönksen. 1990. Metabolic effects of an insulin-like factor causing hypoglycemia in a patient with a haemangiopericytoma. Clin. Endocrinol. 32:769-780.

20. Moller, N., W. F. Blum, A. Mengel, L. B. Hansen, K. G. M. M. Alberti, and O. Schmitz. 1991. Basal and insulin stimulated substrate metabolism in tumour induced hypoglycemia: evidence for increased muscle glucose uptake. Diabetologia. 34:17-20.

21. Unger, R. H. 1966. The riddle of tumor hypoglycemia. Am. J. Med. 40:325-330. (Editorial)

22. August, J. T., and H. H. Hiatt. 1958. Severe hypoglycemia secondary to a nonpancreatic fibrosarcoma with insulin activity. $N$. Engl. J. Med. 258:17-20.

23. Perkoff, G. T., and E. L. Simons. 1963. Hypoglycemia in a patient with a fibrous tumor. Arch. Intern. Med. 112:589-593.

24. Chowdhury, F., and S. J. Bleicher. 1973. Studies of tumor hypoglycemia. Metab. Clin. Exp. 22:663-674.

25. Phelps, M. E., S. C. Huang, E. J. Hoffman, C. Selin, L. S. Sokoloff, and D. E. Kuhl. 1979. Tomographic measurement of local cerebral glucose metabolic rate in humans with (F-18)-fluoro-2-deoxy-D-glucose: validation of method. Ann. Neurol. 6:371-388.

26. Kern, K. A., A. Brunetti, J. A. Norton, A. E. Chang, M. Malawer, E. Lack, R. D. Finn, S. A. Rosenberg, and S. M. Larson. 1988. Metabolic imaging of human extremity musculoskeletal tumors by PET. J. Nucl. Med. 29:181-186.

27. Sokoloff, L., M. Reivich, C. Kennedy, M. H. Des Rosiers, C. S. Patlak, K. D. Pettigrew, O. Sakurada, and M. Shinohara. 1977. The $\left[{ }^{14} \mathrm{C}\right]$ deoxyglucose method for the measurement of local cerebral glucose utilization: theory, procedure, and normal values in the conscious and anesthetized albino rat. J. Neurochem. 28:897-916.

28. Eastman, R. C., R. E. Carson, M. R. Gordon, G. W. Berg, S. Lillioja, S. M Larson, and J. Roth. 1990. Brain glucose metabolism in noninsulin-dependent diabetes mellitus: a study in Pima Indians using positron emission tomography during hyperinsulinemia with euglycemic glucose clamp. J. Clin. Endocrinol. \& Metab. 71:1602-1610.

29. Ratib, O., M. E. Phelps, S. C. Huang, E. Henze, C. E. Selin, and H. R. Schelbert. 1982. Positron tomography with deoxyglucose for estimating local myocardial glucose metabolism. J. Nucl. Med. 23:577-586.

30. Mossberg, K. A., R. W. Rowe, T. J. Tewson, and H. Taegtmeyer. 1989 Rabbit hindlimb glucose uptake assessed with positron-emitting fluorodeoxyglucose. J. Appl. Physiol. 76:1569-1577.

31. Patlak, C. S., R. G. Blasberg, and J. D. Fenstermacher. 1983. Graphical evaluation of blood-to-brain transfer constants from multiple-time uptake data. J. Cereb. Blood Flow Metab. 3:1-7. 
32. Patlak, C. S., and R. G. Blasberg. 1985. Graphical evaluation of blood-tobrain transfer constants from multiple-time-uptake data: generalizations. $J$. Cereb. Blood Flow Metab. 5:584-90.

33. Steele, R. 1959. Influences of glucose loading and injected insulin on hepatic glucose output. Ann. NY Acad. Sci. 82:420-430.

34. deBodo, R. C., R. Steele, N. Altszuler, A. Dunn, and J. S. Bishop. 1963. On the hormonal regulation of carbohydrate metabolism: studies with $\mathrm{C}^{14} \mathrm{glu}$ cose. Recent Prog. Horm. Res. 19:445-448.

35. Insel, P. A., J. E. Liljenquist, J. D. Tobin, R. S. Sherwin, P. Watkins, R. Andres, and $M$. Berman. 1975. Insulin control of glucose metabolism in man: a new kinetic analysis. J. Clin. Invest. 55:1057-1066.

36. Cowan, J. S., and G. Hetenyi, Jr. 1971. Glucoregulatory responses in normal and diabetic dogs recorded by a new tracer method. Metab. Clin. Exp. 20:360-372.

37. Cohn, S. H., D. Vartsky, S. Yasumura, A. Sawitsky, I. Zanzi, A. Vaswani, and K. J. Ellis. 1980. Compartmental body composition based on total-body nitrogen, potassium, and calcium. Am. J. Physiol. 239:E524-530.

38. Lowe, W. L., Jr., S. R. Lasky, D. LeRoith, and C. T. Roberts, Jr. 1988. Distribution and regulation of rat insulin-like growth factor I messenger ribonucleic acids encoding alternative carboxyterminal E-peptides: evidence for differential processing and regulation in liver. Mol. Endocrinol. 2:528-535.

39. Lowe, W. L., Jr., C. T. Roberts, Jr., S. R. Lasky, and D. LeRoith. 1987. Differential expression of alternative 5 ' untranslated regions in mRNAs encoding rat insulin-like growth factor I. Proc. Natl. Acad. Sci. USA. 84:8946-8950.

40. Lowe, W. L., M. Adamo, H. Werner, C. T. Roberts, Jr., and D. LeRoith. 1989. Regulation by fasting of rat insulin-like growth factor I and its receptor. $J$. Clin. Invest. 84:619-626.

41. Perdue, J. F., J. K. Chan, C. Thibault, P. Radaj, B. Bills, and W. H. Daughaday. 1983. The biochemical characterization of detergent-solubilized insulin-like growth factor II receptors from rat placenta. J. Biol. Chem. 258:78007811.

4la. Perdue, J. F., L. K. Gowan, R. W. Hudgins, J. Schevermann, B. Foster, and $\mathrm{S}$. Northcutt-Brown. Development of a specific radioimmuno-assay for $\mathrm{E}$ domain containing forms of insulin-like growth factor II. In Molecular Biology and Physiology of Insulin-like Growth Factors, M. K. Raizada, and D. LeRoith, editors. Plenum Press, New York. 3-4.

42. Zapf, J., Ch. Schmid, H. P. Guler, M. Waldvogel, Ch. Hauri, E. Futo, P. Hossenlopp, M. Binoux, and E. R. Froesch. 1990. Regulation of binding proteins for insulin-like growth factors (IGF) in humans. J. Clin. Invest. 86:952-961.

43. Daniel, W. F. 1983. Biostatistics: A Foundation for Analysis in the Health Sciences. John Wiley and Sons, Inc., New York. 534 pp.

43a. Wasada, T. N. Hizuka, M. Yamamoto, K. Haruki, K. Ikejiri, Y. Oka, T. Asano, M. Aiba, and Y. Hirata. 1992. An insulin-like growth factor II-producing histiocytoma associated with hypoglycemia. Analysis of the peptide, its gene expression, and glucose transporter isoforms. Metab. Clin. Exp. 41:310-316.

44. Daughaday, W. H., and M. Kapadia. 1989. Significance of abnormal serum binding of insulin-like growth factor II in the development of hypoglycemia in patients with non-islet-cell tumors. Proc. Natl. Acad. Sci. USA. 86:67786782 .

45. Zapf, J., H. Walter, and E. R. Froesch. 1981. Radioimmunological determination of insulinlike growth factors I and II in normal subjects and in patients with growth disorders and extrapancreatic tumor hypoglycemia. J. Clin. Invest. 68:1321-1330.

46. Daughaday, W. H., B. Trivedi, and M. Kapadia. 1981. Measurement of insulin-like growth factor II by specific radioreceptor assay in serum of normal individuals, patients with abnormal growth hormone secretion, and patients with tumor-associated hypoglycemia. J. Clin. Endocrinol. \& Metab. 53:289-294.

47. Zapf, J., B. Morell, H. Walker, Z. Laron, and E. R. Froesch. 1980. Serum levels of insulin-like growth factor (IGF) and its carrier protein in various metabolic disorders. Acta Endocrinol. 95:505-517.

48. Kahn, C. R. 1980. The riddle of tumour hypoglycaemia revisited. Clin. Endocrinol. Metab. 9:335-360.

49. MacGorman, L. R., R. A. Rizza, and J. E. Gerich. 1981. Physiological concentrations of growth hormone exert insulin-like and insulin antagonistic effects on both hepatic and extrahepatic tissues in man. J. Clin. Endocrinol. \& Metab. 53:556-559.

50. Saaman, N. A., F. K. Pham, R. V. Sellin, J. F. Fernandez, and R. S. Benjamin. Successful treatment of hypoglycemia using glucagon in a patient with an extrapancreatic tumor. Ann. Intern. Med. 113:404-406.

51. Van Schravendijk, C. F. H., A. Foriers, J. L. Van den Brande, and D. G. Pipeleers. 1987. Evidence for the presence of type I insulin-like growth factor receptors on rat pancreatic A and B cells. Endocrinology. 121:1784-1788.

52. Defronzo, R. A. E. Jacot, E. Jequier, E. Maeder, J. Wahren, and F. P. Felber. 1981. The effect of insulin in the disposal of intravenous glucose: results from indirect calorimetry and hepatic and femoral venous catheterization. Diabetes. 30:1000-1007.

53. Rizza, R. A., L. J. Mandarino, and J. E. Gerich. 1982. Cortisol-induced insulin resistance in man: impaired suppression of glucose production and stimulation of glucose utilization due to a postreceptor defect of insulin action. J. Clin. Endocrinol. \& Metab. 54:131-138.

54. Cerosimo, E., P. W. T. Pisters, G. Pesola, A. Rogatko, N. A. Vydelingum, D. Bajorunas, and M. F. Brennan. 1991. The effect of graded doses of insulin on peripheral glucose uptake and lactate release in cancer cachexia. Surgery (St. Louis). 109:459-467.

55. Dohm, G. L., C. W. Elton, M. S. Raju, N. D. Mooney, R. DiMarchi, W. J. Pories, E. G. Flickinger, S. M. Atkinson, Jr., and J. F. Caro. 1990. IGF-I-stimulated glucose transport in human skeletal muscle and IGF-I resistance in obesity and NIDDM. Diabetes. 39:1028-1032.

56. Caro, J. F., J. Poulos, O. Ittoop, W. J. Pories, E. G. Flickinger, and M. K. Sinha. 1988. Insulin-like growth factor I binding in hepatocytes from human liver, human hepatoma, and normal, regenerating, and fetal rat liver. J. Clin. Invest. 81:976-981.

57. Horecker, B. L., and H. H. Hiatt. 1958. Pathways of carbohydrate metabolism in normal and neoplastic cells. N. Engl. J. Med. 258:177-184

58. Huang, S. C., M. E. Phelps, E. J. Hoffman, K. Sideris, C. J. Selin, and D. E. Kuhl. 1980. Noninvasive determination of local cerebral metabolic rate of glucose in man. Am. J. Physiol. 238:E69-82.

59. Araujo, L. I., P. Camici, T. J. Spinks, T. Jones, and A. Maseri. 1988. Abnormalities in myocardial metabolism in patients with unstable angina as assessed by positron emission tomography. Cardiovasc. Drugs Ther. 2:41-46.

60. Nuutila, P., V. A. Koivisto, J. Knuutti, U. Ruotsalawen, M. Teras, M. Haaparanta, J. Bergman, O. Solin, L. M. Voipio-Pulkki, U. Wegelius, and H. Yki-Järvinen 1991. Quantitation of Operation of the glucose-fatty acid cycle in human cardiac, femoral, and arm muscles using positron emission tomography (PET). Diabetes. 40 (Suppl. 1):156A.

61. Laurent, J., G. Debry, and J. Floquet. 1971. Hypoglycaemic Tumors. Excerpta Medica, Amsterdam. 167 pp. 